\title{
The discipline content design "Fundamentals of Automation and Telemechanics" for the sustainable development of competencies within the framework of educational programs
}

\author{
Grigory Cherezov ${ }^{1, *}$, Elena Rusakova $^{1}$, and Vladimir Tselishchev $^{2}$ \\ ${ }^{1}$ Ural State University of Railway Transport, Kolmogorova Str., 66, 620034 Ekaterinburg, Russia \\ ${ }^{2}$ Irkutsk State Transport University, Chernyshevskogo str., 15, 664074 Irkutsk, Russia
}

\begin{abstract}
The trajectory generation is necessary to achieve sustainable development and the formation of the competencies of a specialist in the field of railway automation and telemechanics and communications. The trajectory is formed through studying the disciplines of the curriculum. The discipline structure is an important factor for the formation of competencies. The article studies the matters related to the discipline content design "Fundamentals of Automation and Telemechanics" for students in the specialty "Train Control Systems" of various specializations. It is shown that despite the fact that the discipline "Fundamentals of Automation and Telemechanics" belongs to the core courses of the educational program, for the sustainable development of the competencies of students of various specializations, it should have a different content. An exemplary discipline content for various specializations is proposed. The formed competences are presented. Along with possible training methods.
\end{abstract}

\section{Introduction}

The department "Automation, Telemechanics and Communication in Railway Transport" is a graduate department of the Ural State University of Railway Transport, which trains students in the specialty 23.05.05 "Train Control Systems" in the specializations "Automation and Telemechanics in Railway Transport" and "telecommunication systems and Networks in Railway Transport".

\section{Materials and Methods}

The training of students is carried out on the basis of the federal state educational standard of higher education (FSES $3++$ ) [1] and the approximate principal educational program (APEP) [2]. APEP contains an approximate curriculum, a calendar training schedule and

${ }^{*}$ Corresponding author: gcherezov@usurt.ru 
work programs of disciplines (modules) and practices in the specialty 23.05.05 "Train Control Systems".

The discipline "Fundamentals of Automation and Telemechanics" (FAT) belongs to the compulsory part of block 1 , is studied in the 4th and 5th semesters, forms the competence of PC-1 and PC-4 [2]. Midterm assessment in the discipline is carried out in the 4th semester in the form of a test with grading, and in the 5th semester - in the form of an exam.

The content of this discipline is regulated by APEP (Table 1).

Table 1. Content of FAT discipline

\begin{tabular}{|c|c|}
\hline Index & Summary of discipline (modules) and practices \\
\hline B1.B.D.30 & $\begin{array}{l}\text { The main elements of automation and telemechanics systems. Definitions and } \\
\text { concepts of automation and telemechanics. } \\
\text { (The exact content is selected based on the specialization requirements) } \\
\text { Automation systems. Basic concepts, purpose and classification of automatic } \\
\text { systems. } \\
\text { Telemechanics systems. The concept of telemechanics systems, their classification, } \\
\text { functional schemes. Types and methods of information transmission in } \\
\text { telemechanics systems. Classification and characteristics of codes. } \\
\text { Coding methods. Effective coding. Protective coding. Construction principles and } \\
\text { types of telemechanical systems. Remote control and remote signalling RC-RS. } \\
\text { RC-RS objects in railway transport. Organization of RC-RS message transmission } \\
\text { channels. Functional schemes and main nodes of telemechanical systems. } \\
\text { Telemetering. Systems synchronization methods. Time-division systems }\end{array}$ \\
\hline
\end{tabular}

The analysis of the brief content of FAT discipline shows that the main sections that should be studied in the 4th and 5th semesters are "Automation" and "Telemechanics", respectively. The exemplary educational program states that the "exact content" of the "Automation" section (the main elements of automation and telemechanics systems, as well as the basic concepts of automation and telemechanics) "is selected based on the specialization requirements". And the content of the section "Telemechanics" is described sufficiently detailed.

APEP in the specialty 23.05.05 "Train Control Systems" was drawn up without taking into account specializations. It determines the general tasks of professional activity (the organization of operation and maintenance of train control systems, the implementation of technical control and quality management in the design, manufacture, operation, maintenance and repair of train control systems) that graduates will have to solve.

Mechanisms of automation and telemechanics of railways and subways are the objects of professional activity of graduates of the specialization "Automation and telemechanics in railway transport". And stationary and mobile means of communication of railways and subways, that provide train traffic control are the objects of professional activity of graduates of the specialization "Telecommunication systems and networks of railway transport". These objects have different technical and technological equipment, as well as a different degree and rate of development. Therefore, the content of FAT discipline presented requires further specification.

\section{Results and discussions}

Automation is the first section of the discipline, which is a field of science that studies theory and creates principles of building systems that operate without human involvement or an automatically operating set of devices and mechanisms. Automation elements are understood as constructively complete devices performing independent functions 
As defined in [3, 4], the main elements of automation are sensors, actuating units and relays. Special consideration is given to the latter due to the fact that most of the railway automation systems are relay. In view of this, the study of various types of relays (neutral, polarized, alternating current, etc.) is relevant for the specialization "Automation and telemechanics in railway transport". Therefore, when drawing up the work program of FAT discipline, an automation system should be understood as a system consisting of a set of relays (electromagnetic, contactless, etc.) and other devices (contactless, digital, microprocessor). So, the basic topics for study are "Basic concepts and definitions of the discipline of automation", "Classification and principles of operation of sensors of automation systems", "General information and principles of operation of a neutral electromagnetic relay of railway automation", "Pull curve and speed/load curve of relays", "Transient processes in DC electromagnetic relays, methods of deceleration and acceleration of relay operation", "Polarized, combined, code relays", "AC relays", "Magnetic reed relays", "Electronic relays".

Modern telecommunications technologies are built upon the use of global computer networks and are a set of algorithms, methods and transmission facilities. In this connection, transmission facilities mean some digital devices. Therefore, it is impractical to give a detailed consideration of automation systems from the perspective of a set of mechanisms and devices that operate automatically and are relay or contactless devices.

For the specialization "Telecommunication systems and networks of railway transport", automation should be understood as a set of instruments and devices constituting an information-gathering system [5]. For that reason, "Basic concepts and definitions of the discipline of automation" (in terms of the classification and structure of information collection systems), "Hardware of information collection systems" (measuring converters, $\mathrm{A} / \mathrm{D}$ converters/DA converters, various interfaces and network devices), "Software of information collection systems" should be considered as the major issues.

Telemechanics is the second section of the discipline, which is a scientific discipline that considers the theory and technical means of converting and transmitting information over a distance (via wired or wireless communication lines) to control production processes with partial or complete automation of the processes of obtaining, transmitting, receiving and using this information.

Telemechanical systems, as a set of technical equipment for control centers and monitoring stations, peripheral equipment, communication lines and channels, are widely used in railway automation and telemechanics. Most centralized dispatching control systems are built according to the principles of remote control and remote signaling.

Modern centralized dispatching control systems are microprocessor-based and use modems and special protocols for transmitting information messages [4]. This is why it is advisable to include in the course questions the study of information transfer protocols, local and global networks, as well as the basics of SCADA (Supervisory control and data acquisition) systems. This will allow the future graduate to be prepared for handling the modern challenges.

If we consider the section "Telemechanics" in terms of the specialization "Telecommunication systems and networks of railway transport", it is common knowledge that telemechanics systems are not used in communication facilities. At the same time, this does not mean that students should not get acquainted with the fundamentals of telemechanics (the concept of telemechanics systems, their classification, principles of construction and types of telemechanical systems, remote control and remote signalling (RC-RS), organization of RC-RS message transmission channels), since RC-RS signals can be transmitted through railway communication channels. For this purpose, remote control systems, telesignalling, as well as telemetering should be paid special attention to, 
excluding from consideration the issues of codes and code formation, which are studied in the discipline "Theory of signal transmission" in the 5th semester.

\section{Conclusions}

Based on the curriculum, the issues examined in FAT discipline and the competencies formed in this case can be presented in the form of Table 2.

Table 2. Issues and competencies under consideration

\begin{tabular}{|c|c|}
\hline $\begin{array}{c}\text { "Automation and telemechanics in railway } \\
\text { transport" }\end{array}$ & $\begin{array}{c}\text { "Telecommunication systems and railway } \\
\text { transport networks" }\end{array}$ \\
\hline \multicolumn{2}{|c|}{ Automation } \\
\hline $\begin{array}{l}\text { Fundamentals and definitions of the discipline } \\
\text { automation }\end{array}$ & $\begin{array}{l}\text { Fundamentals and definitions of the discipline } \\
\text { automation }\end{array}$ \\
\hline $\begin{array}{l}\text { Classification and operating principles of } \\
\text { automatic system sensors }\end{array}$ & $\begin{array}{l}\text { Sensors and transducers of information collection } \\
\text { systems. }\end{array}$ \\
\hline $\begin{array}{l}\text { General information and principles of } \\
\text { operation of the neutral electromagnetic relay } \\
\text { of railway automation }\end{array}$ & $\begin{array}{l}\text { Analog-to-digital and digital-to-analog } \\
\text { transducers. Controllers }\end{array}$ \\
\hline Pull curve and speed/load curve of relays & Industrial network interfaces \\
\hline $\begin{array}{l}\text { Transient processes in DC electromagnetic } \\
\text { relays, methods of deceleration and } \\
\text { acceleration of relay operation }\end{array}$ & Interface converters. Network devices \\
\hline Polarized, combined, code relays & Industrial network communication protocol \\
\hline AC relays & Controller programming systems \\
\hline Magnetic reed relays & Real-time operating systems \\
\hline Electronic relays & Internet technologies in automation \\
\hline \multicolumn{2}{|c|}{ Telemechanics } \\
\hline $\begin{array}{l}\text { Telemechanics systems. The concept of } \\
\text { telemechanics systems, their classification, } \\
\text { functional schemes. Types and methods of } \\
\text { information transmission in telemechanics } \\
\text { systems }\end{array}$ & $\begin{array}{l}\text { Telemechanics systems. The concept of } \\
\text { telemechanics systems, their classification, } \\
\text { functional schemes. Types and methods of } \\
\text { information transmission in telemechanics } \\
\text { systems }\end{array}$ \\
\hline $\begin{array}{l}\text { Classification and characteristics of codes. } \\
\text { Coding methods. Effective coding. Protective } \\
\text { coding }\end{array}$ & $\begin{array}{llcr}\text { Construction } & \text { principles and types of } \\
\text { telemechanical } & \text { systems. Remote } & \text { control and } \\
\text { remote signalling RC-RS } & & & \end{array}$ \\
\hline $\begin{array}{l}\text { Construction principles and types of } \\
\text { telemechanical systems. Remote control and } \\
\text { remote signalling RC-RS. RC-RS objects in } \\
\text { railway transport }\end{array}$ & RC-RS objects in railway transport \\
\hline $\begin{array}{l}\text { Organization of RC-RS message transmission } \\
\text { channels }\end{array}$ & $\begin{array}{l}\text { Organization of RC-RS message transmission } \\
\text { channels }\end{array}$ \\
\hline $\begin{array}{l}\text { Functional schemes and main nodes of } \\
\text { telemechanical systems }\end{array}$ & $\begin{array}{l}\text { Functional schemes and methods of } \\
\text { synchronization of telemechanical systems }\end{array}$ \\
\hline Telemetering & Telemetering \\
\hline $\begin{array}{l}\text { Systems synchronization methods. Time- } \\
\text { division systems }\end{array}$ & $\begin{array}{l}\text { Communication network monitoring principles } \\
\text { and methods }\end{array}$ \\
\hline SCADA systems & SCADA systems \\
\hline $\begin{array}{l}\text { Internet technologies in automation of } \\
\text { technological processes }\end{array}$ & $\begin{array}{l}\text { Integrated system for monitoring and } \\
\text { administration of communication networks of } \\
\text { Russian Railways JSC }\end{array}$ \\
\hline
\end{tabular}

The study of the questions given in Table 2 will allow students to form the following knowledge: 
PC-1.1: knows the mechanism, principle of operation, technical characteristics and design features of the main elements, assemblies and mechanisms of the train control system;

PC-4.1: knows the element base (types and physical principles of operation) for the development of schematic engineering solutions for elements and mechanisms of the train control system;

As well as knowledge and skills:

PC-1.2: uses knowledge of fundamental engineering theories to organize and perform works on installation, operation, maintenance, repair and retrofit of the train control system;

PC-4.2: applies methods of engineering calculations, design and analysis of the characteristics of elements and mechanisms of the train control system;

PC-4.3: applies the basics of the abstract theory of automata, the theory of electrical engineering and electrical circuits, electronic, discrete and microprocessor-based units and information systems for the analysis, synthesis, development and design of elements and mechanisms of the train control system.

Passive, active and interactive training methods are used in the formation of knowledge, skills and abilities in the field of theoretical foundations of automation and telemechanics.

The passive method, in which the student acts as a listener, is used when conducting a lecture, which begins with designation of the topic and plan, as well as the necessary literature for independent preparation. One aspect of conducting a lecture on FAT discipline is the need to link the issues under consideration (usually 3-4) with the previously studied provisions and laws of physics and the theoretical basics of electrical engineering, as well as subsequent disciplines of specializations. The introduction of interdisciplinary connections and their designation is an important aspect in the formation of comprehensive knowledge and skills in students, along with an understanding of the curriculum structure and the training complexity according to the chosen specialization $[6,7,8]$.

Laboratory classes use active and interactive training methods, during which students in small groups perform experiments with automation and telemechanics mechanisms on the instructions of the teacher. An important aspect in such event is the need to organize interaction not only between the teacher and the student, but also between students within small groups. This is accomplished by providing each student with a specific role during the implementation of the experience on the physical model and the subsequent preparation of the laboratory report.

Another aspect of the formation of expertise, knowledge and skills directed at performance of professional activity tasks is the possibility of training using electronic means that are used at Russian Railways JSC. This is, for example, an online training system for signaling distances, training centers, secondary and higher educational institutions, signal departments of industrial transport, design organizations (ATSSignaling, St. Petersburg State Transport University) and online training systems (Distance Learning System, NovATrans) designed to organize the remote e-learning process. These systems include electronic trainers, $3 D$ models of the main mechanisms of railway automation and telemechanics, brief theoretical information and test tasks.

The proposed changes in the structure of the working program of the discipline "Fundamentals of Automation and Telemechanics", taking into account specializations, as well as the joint use of passive, active and interactive teaching methods, in terms of the main aspects of teaching the discipline for the corresponding specialization, will allow the complete coverage of the automation of control of technological processes to the fullest extent possible in such subject areas as railway automation and railway communication. And this, in turn, will assist in the sustainable development of the competencies necessary for a future graduate in their professional activities. 


\section{References}

1. Federal State Educational Standard for the specialty 23.05.05 "Train control systems" (specialty level) [Electronic resource]: Approved by order of the Ministry of Education and Science of Russia No. 217 dated March 27, 2018, http://gosvo.ru/

2. Approximate principal educational program in the specialty 23.05 .05 "Train control systems", http://пооп.pф/

3. Theoretical basics of railway automation and telemechanics: Textbook for universities of railway transport, 394 (2008)

4. D.V. Shalyagin, A.V. Gorelik, Yu.G. Borovkov, A.A. Volkov, Automation, telemechanics and communication in railway transport: textbook: in three parts, 424 (2019)

5. E.A. Rusakova, Information collection systems: textbook, 259, 1 (2016)

6. L.V. Astakhova, Integration of education, 22(1), 60 (2018)

7. Ch. Lystbaek, Research methodology competence development in higher education (2016)

8. P. John Surej, Contaduría y Administración, 60, 230 (2015) 